\title{
Augmented Reality and the Prospects for Applying Its in the Training of Future Engineers
}

\author{
Natalya V. Rashevska ${ }^{10000-0001-6431-2503]}$ and Vladimir N. Soloviev ${ }^{20000-0002-4945-202 X]}$ \\ ${ }^{1}$ State Institution of Higher Education "Kryvyi Rih National University", \\ 11, Vitali Matusevich St., Kryvyi Rih, 50027, Ukraine \\ nvr1701@gmail.com \\ ${ }^{2}$ Kryvyi Rih State Pedagogical University, 54, Gagarina Ave., Kryvyi Rih, 50086, Ukraine \\ vnsoloviev2016@gmail.com
}

\begin{abstract}
The education system of Ukraine is closely linked with the world education trends, therefore it requires constant renewal and expansion. One of the progressive areas of organizing studying process is creating the studying environment which will allow students to reveal their intellectual potential while searching for the necessary knowledge. That's why the purpose of the article is analysis of the concept of augmented reality and prospects of its application in the process of training future engineers. The object of study is the system of training future engineers and the subject is using of augmented reality technologies in the process of training future engineers. The research method is analyzing the impact of the augmented reality technologies on the training future engineers. During the research, we have identified positive aspects of the augmented reality technologies in the process of training future engineers. We have defined the stages of creating some methodical system components of teaching fundamental disciplines in the higher technical school through interdisciplinary integration and technologies of augmented reality.
\end{abstract}

Keywords: technology of augmented reality; process of training future engineers.

\section{Introduction}

The key to human success is our education, which takes on a new feature in the 21st Century - learning throughout our life, and the ability to apply this knowledge in practice.

The rapid change of technology, the development of information and communication technologies, the change in the paradigm of educating has led to the fact that the amount of knowledge necessary for a person to succeed is constantly changing and increasing, and therefore there is a need to acquire new knowledge quickly and qualitatively, and be able to apply our knowledge in everyday life and educating.

Formal educating in a higher technical educational institution under the traditional system in the 20th century has been replaced by new forms of educating - distance, 
electronic and mobile [21]. Each of these forms has its own positive and negative features, but none of them was able to replace the traditional educating process - "live" communication between a teacher and a student. One of the models of educating that was able to combine the traits of traditional educating with innovation was the model of mixed educating (blended learning), which enabled the student to become an active seeker of their own knowledge [18; 19].

For more immersion of the student into the educating process, in order to better visualize the knowledge gained, technologies of the complementary (mixed, augmented, virtual etc.) reality, which make it possible to change the approach to the organization of the process of educating in higher education are more relevant in recent times [16].

\section{Related work}

The analysis of scientific sources provided an opportunity to argue that the use of technologies of augmented reality in the educating process:

— increases motivation for educating [9] and self-motivation [13];

- increases the quality of education $[5 ; 8 ; 12]$;

- creates conditions for obtaining more thorough knowledge [17];

- creates conditions for improving the quality of inclusive education [14];

- provides the opportunity to build an educating process based on the model of mixed educating $[4 ; 23]$ with the involvement of mobile information and communication technologies [10].

\section{The Aim of the Study}

Thomas Preston Caudell, the author of the term "augmented reality", in 1990 was the engineer of research laboratory at Boeing [6], and later, with the development of information and communication technologies, the term gained widespread consumption not only as a technology expansion of reality, but and as technologies that can be used in the learning process.

That is why, the purpose of the article is to analyze the concept of augmented reality and the prospects for its application in the process of preparing future engineers.

\section{$4 \quad$ Discussion and Results}

Let us analyze the notion of "augmented reality" in the historical context [20]. Four years later, from the first mention of the concept of "augmented reality" by Caudell in 1994, the article "Taxonomy of mixed reality" was published, in which the authors consider such concepts as virtual reality, mixed reality and augmented reality [15]. In opinion Paul Milgram and Fumio Kishino, augmented reality is a technology by which the user's capabilities are expanded by introducing into the user's perception field various virtual objects in real time mode. 
In 1997, Ronald T. Azuma first formulated the basic principles that characterize systems using augmented reality:

1. the combination of real and virtual world;

2. interaction in real time;

3. work with three-dimensional space, and also provides an interpretation of the concept of augmented reality.

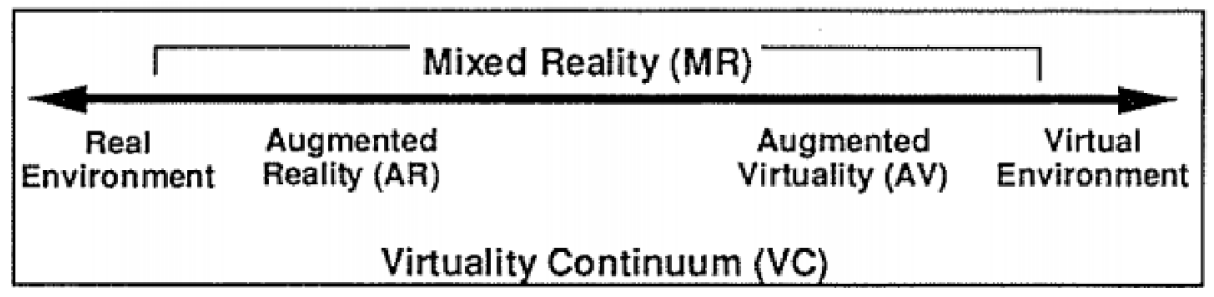

a)

\begin{tabular}{|l|cc|}
\hline & Where / What & $\begin{array}{l}\text { Where } \\
+ \text { What }\end{array}$ \\
\hline $\begin{array}{c}\text { World } \\
\text { Unmodelled }\end{array}$ & Worid Partially Modelled & $\begin{array}{c}\text { World } \\
\text { Completely } \\
\text { Modelled }\end{array}$ \\
& Extent of World Knowledge (EWK) \\
\hline
\end{tabular}

b)

\begin{tabular}{|ccccc|}
\hline $\begin{array}{c}\text { Conventional } \\
\text { (Monoscopic) } \\
\text { Video }\end{array}$ & $\begin{array}{c}\text { Colour } \\
\text { Video }\end{array}$ & $\begin{array}{c}\text { Stereoscopic } \\
\text { Video }\end{array}$ & $\begin{array}{c}\text { High } \\
\text { Definition } \\
\text { Video }\end{array}$ & 3D HDTV \\
\hline $\begin{array}{c}\text { Simple } \\
\text { Wireframes }\end{array}$ & $\begin{array}{c}\text { Visible } \\
\text { Surface } \\
\text { Imaging }\end{array}$ & $\begin{array}{c}\text { Shading, } \\
\text { Texture, } \\
\text { Transparency }\end{array}$ & $\begin{array}{c}\text { Ray } \\
\text { Tracing, } \\
\text { Radiosity }\end{array}$ & $\begin{array}{c}\text { Real-time, } \\
\text { Hi-fidelity, } \\
\text { 3D Animation }\end{array}$ \\
& Reproduction Fidelity (RF) & \\
\hline
\end{tabular}

c)

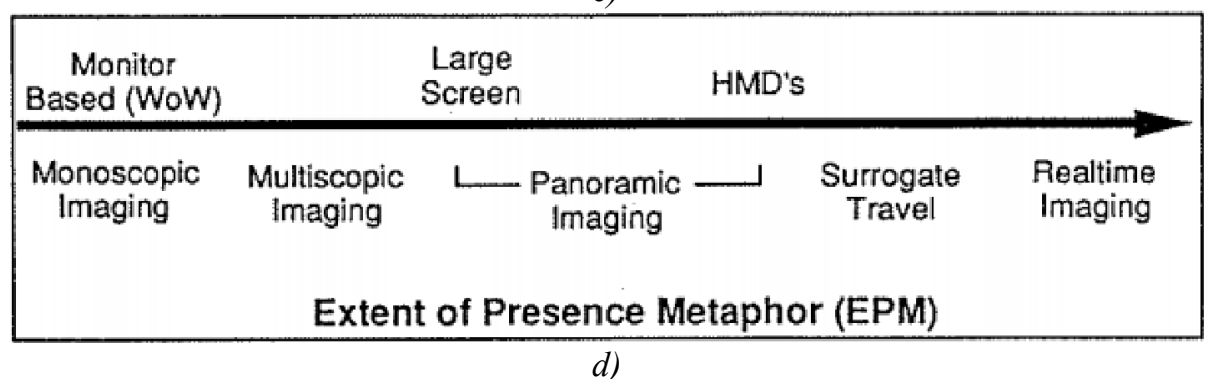

Fig. 1. Milgram-Kishino taxonomy of mixed reality visual displays: a) simplified representation of a "virtuality continuum"; b) extent of World Knowledge dimension; c) Reproduction Fidelity dimension; d) extent of Presence Metaphor dimension 
In his view, augmented reality is the technology of integrating real and computer-generated virtual objects in the real world [2].

Later, in 2001, scientist added to this list the application of augmented reality applications by incorporating virtual and computer content into it, allowing a wider application of mixed reality through a simulation that takes place in a virtual rather than a real world [1].

A wide application of the term "augmented reality" began to acquire with the development of software and hardware for its creation and support.

According to Evgeniia A. Daineko [7], there are several reasons for the growth in the popularity of technologies of augmented reality: 1) interactivity, 2) accessibility, 3) realism, 4) innovativeness.

So, augmented reality is technology that allows you to combine computer-aided 3D graphics, animation, video and textual information with real-time objects [3]; it is a mixed reality that can be perceived by a person, and supplemented with the help of a computer with elements of some reality [22]; it is a technology that combines the physical environment of a person with a layer of virtual reality in real time. It is used to visually supplement printed material with various virtual objects: text, sound, video, etc. [11]; this environment with the addition of the physical world with digital data, are perceived as elements of real life. When creating augmented reality in space in real time, objects are placed using special software and devices for their reproduction [16].

Using the technologies of augmented reality in the process of preparing future engineers will allow:

- to carry out the integration of fundamental disciplines and visualize the educating process;

- make the learning process holistic, vivid, rich and will strengthen the fundamentalization of engineering education;

- to build an open system of education that will provide each student the opportunity to create a personal trajectory of educating;

- to expand the boundaries of educating - acquire knowledge using the teaching materials of the world's leading technical universities;

- to make the educating process individualized and adapted for each student;

- to increase cognitive activity of students in the process of teaching fundamental disciplines and make the student an active competitor of knowledge;

- to support independent work of the student;

- to intensify the educating process;

- to increase the student's creative thinking and expand the vision of the world.

\section{Conclusion}

Summarizing the above, it can be argued that for the further implementation of certain components of the application of augmented reality technologies in the process of educating future engineers, it is necessary: 
- to identify means of augmented reality that can be used in the process of teaching fundamental disciplines;

- to determine the forms and methods of organizing the process of teaching fundamental disciplines, taking into account the augmented reality in the higher technical school;

- to develop educating materials for visualization of the educating process, which combined theoretical and practical information on the subjects of the specialty and implemented intersubject communications;

- to develop a methodology for teaching fundamental disciplines based on the technology of augmented reality and experimentally test or disprove its effectiveness.

\section{References}

1. Azuma, R., Baillot, Y., Behringer, R., Feiner, S., Julier, S., MacIntyre, B.: Recent Advances in Augmented Reality. IEEE Computer Graphics and Applications. 21(6), 34-47 (2001)

2. Azuma, R.T.: A Survey of Augmented Reality. Presence: Teleoperators and Virtual Environments. 6(4), 355-385 (1997). doi:10.1162/pres.1997.6.4.355

3. Bova, V.V., Lezhebokov, A.A., Nuzhnov, E.V.: Obrazovatelnye informatcionnye sistemy na osnove mobilnykh prilozhenii s dopolnennoi realnostiu (Educational information system based mobile applications with augmented reality). Izvestiya SFedU. Engineering sciences. 6(167), 200-210 (2015)

4. Chang, Y.H., Liu, J.-ch.: Applying an AR Technique to Enhance Situated Heritage Learning in a Ubiquitous Learning Environment. The Turkish Online Journal of Educational Technology. 1(3), 21-32 (2013)

5. Civelek, T., Ucar, E., Ustunel, H., Aydin, M.K.: Effects of a Haptic Augmented Simulation on K-12 Students' Achievement and their Attitudes towards Physics. Eurasia Journal of Mathematics, Science \& Technology Education. 10(6), 565-574 (2014). doi: 10.12973/eurasia.2014.1122a

6. Coimbra, T., Cardoso, T., Mateus, A.: Augmented Reality: an Enhancer for Higher Education Students in Math's learning? Procedia Computer Science. 67, 332-339 (2015). doi:10.1016/j.procs.2015.09.277

7. Daineko, E.A., Ipalakova, M.T., Serikov, S.S., Zhanabai, G.K.: Primenenie tekhnologii dopolnennoi realnosti v obrazovanii (Application of augmented reality technologies in education). In: Proceeding of the $13^{\text {th }}$ International scientific and practical conference on Fundamental and applied research in the modern world, 17 March 2016, vol. 1, pp. 26-28. Strategiia budushchego, St. Petersburg (2016)

8. Estapa, A., Nadolny, L.: The Effect of an Augmented Reality Enhanced Mathematics Lesson on Student Achievement and Motivation. Journal of STEM Education: Innovations and Research. 16(3), 40-48 (2015)

9. Ferrer-Torregrosa, J., Torralba, J., Jimenez, M.A., García, S., Barcia, J.M.: ARBOOK: Development and Assessment of a Tool Based on Augmented Reality for Anatomy. Journal of Science Education and Technology. 24(1), 119-124 (2015). doi:10.1007/s10956-0149526-4

10. Ismail, I., Idrus, R.M., Gunasegaran, Th.: Motivation, Psychology and Language Effect on Mobile Learning in Universiti Sains Malaysia. International Journal of Interactive Mobile Technologies. 4(4), 31-36 (2010) 
11. Ivanchenko, A.E., Ignatova, T.A.: Tekhnologiia dopolnennoi realnosti v obrazovanii (Technology of additional reality in education). Alleia nauki. 4(10), 322-324 (2017)

12. Lu, S.-J. , Liu, Y.-C.: Integrating augmented reality technology to enhance children's learning in marine education. Environmental Education Research. 21(4), 525-541 (2015). doi:10.1080/13504622.2014.911247

13. Martin-Gutierrez, J., Guinters, E., Perez-Lopez, D.: Improving Strategy of Self-Learning in Engineering: Laboratories with Augmented Reality. Procedia - Social and Behavioral Sciences. 51, 832-839 (2012). doi:10.1016/j.sbspro.2012.08.249

14. McMahon, D., Cihak, D.F., Wright, R.: Augmented Reality as a Navigation Tool to Employment Opportunities for Postsecondary Education Students With Intellectual Disabilities and Autism. Journal of Research on Technology in Education. 47(3), 157-172 (2015). doi:10.1080/15391523.2015.1047698

15. Milgram, P., Kishino, F.: A taxonomy of mixed reality visual displays. IEICE Transactions on Information and Systems. E77-D(12), 1321-1329 (1994)

16. Modlo, Ye.O., Yechkalo, Yu.V., Semerikov, S.O., Tkachuk, V.V.: Vykorystannia tekhnolohii dopovnenoi realnosti u mobilno oriientovanomu seredovyshchi navchannia VNZ (Using technology of augmented reality in a mobile-based learning environment of the higher educational institution). Naukovi zapysky, Seriia: Problemy metodyky fizykomatematychnoi i tekhnolohichnoi osvity. 11(1), 93-100 (2017)

17. Pérez-López, D., Contero, M.: Delivering educational multimedia contents through an augmented reality application: A case study on its impact on knowledge acquisition and retention. The Turkish Online Journal of Educational Technology. 12(4), 19-28 (2013)

18. Rashevska, N.V., Semerikov, S.O., Slovak, K.I., Striuk, A.M.: Model kombinovanoho navchannia u vyshchii shkoli Ukrainy (The blended learning model in Ukrainian higher education). In: Sbornik nauchnykh trudov, pp. 54-59. Miskdruk, Kharkiv (2011)

19. Rashevska, N.V., Semerikov, S.O.: Modeli zmishanoho navchannia (Blended learning models). New computer technology. 11, 103-104 (2013)

20. Semerikov, S.O., Striuk, A.M., Slovak, K.I., Rashevska, N.V., Yechkalo, Yu.V.: Liudyna z kompiuternym oblychchiam (do 80-richchia Aivena Edvarda Sazerlenda) (A man with a computer face (to the 80th anniversary of Ivan Edward Sutherland)). New computer technology. 16, 9-24 (2018)

21. Semerikov, S.O., Striuk, M.I., Moiseienko, N.V.: Mobilne navchannia: istoryko-tekhnolohichnyi vymir (Mobile learning: historical and technological dimension). In: Konoval, O.A. (ed.) Teoriia i praktyka orhanizatsii samostiinoi roboty studentiv vyshchykh navchalnykh zakladiv (Theory and practice of organization of independent work of students of higher educational institutions), pp. 188-242. Knyzhkove vydavnytstvo Kyreievskoho, Kryvyi Rih (2012)

22. Striuk, A., Rassovytska, M., Shokaliuk, S.: Using Blippar Augmented Reality Browser in the Practical Training of Mechanical Engineers. In: Ermolayev, V., Suárez-Figueroa, M.C., Yakovyna, V., Kharchenko, V., Kobets, V., Kravtsov, H., Peschanenko, V., Prytula, Ya., Nikitchenko, M., Spivakovsky A. (eds.) Proceedings of the 14th International Conference on ICT in Education, Research and Industrial Applications. Integration, Harmonization and Knowledge Transfer (ICTERI, 2018), Kyiv, Ukraine, 14-17 May 2018, vol. II: Workshops. CEUR Workshop Proceedings (CEUR-WS.org), vol. 2104, pp. 412-419 (2018)

23. Wang, H.-Y., Duh, H.B.-L., Li, N., Lin, Tz.-J., Tsai, Ch.-Ch.: An Investigation of University Students' Collaborative Inquiry Learning Behaviors in an Augmented Reality Simulation and a Traditional Simulation. Journal of Science Education and Technology. 23(5), 682-691 (2014). doi:10.1007/s10956-014-9494-8 